\title{
KEDUDUKAN HUKUM WANITA YANG MULIH DAHA DI BANJAR MUNGGU KECAMATAN MENGWI KABUPATEN BADUNG
}

\author{
Ni Komang Tri Intan Suaristiwayani, I Ketut Sukadana, Diah Gayatri Sudibya \\ Fakultas Hukum Universitas Warmadewa, Denpasar-Bali, Indonesia \\ triintansuaris29@gmailcom, sukadanafhunwar@gmailcom, diahgayatrisudibya@gmailcom
}

\begin{abstract}
Abstrak
Wanita yang kembali kerumah orang tuanya karena perceraian akan berstatus mulih daha Dengan status mulih daha maka wanita akan memiliki swadharma (kewajiban) dan swadikara (hak) sebagaimana halnya sebelum berlangsungnya perkawinan dirumah masing-masing Banjar Munggu telah dijumpai beberapa perempuan yang mengalami kasus mulih daha Rumusan Masalah Bagaimanakah prosedur Kedudukan wanita yang mulih daha di Banjar Munggu Mengwi Badung? Penelitian ini menggunakan jenis penelitian hukum empiris dengan pendekatan sosiologi hukum dalam teknik pengumpulan data kualitatif yang secara diskriptif yaitu memilih dan meringkas data yang diperoleh menjadi data yang relevan. Hasil penelitian ini adalah wanita yang mulih daha karena perceraian tidak mendapatkan warisan dari dan harta kekayaan suaminya dan atau harta orang tuanya terkecuali adalah harta yang didapat bersama dalam pewarisan dan untuk di Banjar Munggu Mengwi tentang ketentuan waris bagi wanita yang mulih daha sangat jelas diatur dalam Awig-Awig banjar Adat bahwa tidak diperkenankan untuk bergabung dalam organisasi desa
\end{abstract}

Kata Kunci: Hukum Adat; Wanita Mulih Daha

\begin{abstract}
For Balinese indigenous people, a woman returning to her parents' home due to divorce has the status of mulih daha. With this status, a woman will have swadharma (obligations) and swadikara (rights) just like before the marriage took place in their respective homes. Several women who have experienced a mulih daha case have visited Banjar Munggu to regain their rights and carry out their obligations. This study examines the procedure for the return of a Balinese woman with the status of mulih daha and their customary position in Banjar Munggu Mengwi Badung. To achieve this goal, this research was conducted using an empirical legal research method with a sociological approach to law. Data were collected through selecting and summarising the data obtained from applicable legal provisions into relevant data with the object of the study. The results reveal that a woman with mulih daha status as a result of divorce does not have the right to inherit from her husband's assets and / or that of their parents', except from joint assets in inheritance. In Banjar Munggu Mengwi, the inheritance provisions for women with mulih daha status are clearly stipulated in the Awig-Awig of Banjar Adat, stipulating that every woman with the status of mulih daha is prohibited from joining in the village organisation.
\end{abstract}

Keywords: Customary Law; Legal Status; Mulih Daha Woman

\section{PENDAHULUAN}

Setiap perkawinan yang dilangsungkan tentu mengharapkan adanya kesejahteraan ketentraman dan kebahagiaan dalam kehidupan berumah tangga. Dalam hukum adat yang berlaku di Bali disebutkan bahwa apabila putusnya perkawinan karena salah satu pihak meninggal dunia maka suami maupun istri dinamakan Balu yang dapat diartikan seseorang dapat memiliki status janda atau duda disebabkan karena salah satu pasangannya meninggal dunia Apabila putusnya perkawinan karena perceraian dalam hukum adat di Bali dinamakan Sapihan Sapihan dalam hubungannya dengan perceraian ini berarti tidak ada yang kalah maupun menang (Windia, 2009). Jadi dalam perceraian ini istri maupun suami diserahkan untuk menyelesaikan hak maupun kewajibannya sendiri-sendiri dan yang terakhir putusnya perkawinan karena putusan Pengadilan (Fahriyanti, 2019). Tujuan perkawinan itu sangat mulia, maka seharusnya perkawinan tersebut dilaksanakan sesuai dengan ketentuan ajaran agama dan peraturan perundang- undangan yang berlaku. Akan tetapi dalam kenyataannya, masih banyak yang tidak 
mematuhi undang-undang tersebut, sehingga tidak dapat dipungkiri bahwa seringkali terjadi permasalahan serius dalam suatu perkawinan. Menurut (Nasir, 2012) Perceraian berdampak buruk terhadap kedua belah pihak, dan dapat juga mengorbankan anak-anak dan masyarakat pada umumnya.

Faktor putusnya perkawinan perceraian menjadikan suatu dasar adanya mulih daha namun tidak seluruhnya wanita yang bercerai dapat berstatus mulih daha Kedudukan mulih daha tidaklah merupakan hak yang melekat pada diri seorang janda sehingga otomatis memperoleh kedudukan sebagai seorang gadis atau deha Mulih daha harus dilakukan dengan persetujuan dari keluarganya termasuk pada ikatan-ikatan dadia atau keluarga besar yang masing-masing mempunyai ikatan di Bali disebut tali sesana (K. I. G. Ketut, 2007). Kenyataannya fenomena yang muncul dalam masyarakat tidak setiap perkawinan yang dilangsungkan dapat berjalan sebagaimana tujuan perkawinan yang dikehendaki oleh pasangan suami istri tersebut Perkawinan dapat putus baik karena kematian salah satu pihak atau karena perceraian Akibat perceraian terhadap status suami atau istri dalam keluarga pada umumnya pihak yang berstatus purusa akan kembali kerumah orang tuanya Dalam perkawinan biasa wanita yang kembali kerumah orang tuanya karena perceraian akan berstatus mulih daha di rumah orang tuanya Dengan status mulih daha maka wanita akan memiliki swadharma (kewajiban) dan swadikara (hak) sebagaimana halnya sebelum berlangsungnya perkawinan dirumah orang tua masing-masing (N. Ketut \& Adnyani, 2019).

Banjar Munggu Mengwi sendiri dijumpai beberapa kasus terkait yang berhubungan dengan perempuan mulih daha yang mengalami permasalahan yang sama dengan yang dipaparkan diatas Di Kecamatan Mengwi tepatnya di Banjar Munggu telah dijumpai beberapa perempuan yang mengalami kasus mulih daha dimana permasalah mulih daha di banjar munggu ditangani oleh penjuru banjar dan melibatkan keluarga yang bersangkutan dengan melaporkan kepada penjuru adat lengkap dengan identitasnya dan di siarkan permasalahan ini dalam rapat banjar. Adapun tujuan dari penelitian ini untuk mengetahui dan memahami prosedur wanita yang mulih daha di Banjar Munggu Mengwi Badung dan untuk mengetahui memahami kedudukan hukum wanita yang mulih daha di Banjar Munggu Mengwi Badung

\section{METODEPENELITIAN}

Metode penelitian yang digunakan dalam penelitian ini adalah penelitian hukum empiris yaitu dengan melakukan penelitian berdasarkan narasumber menelaah yang menjadi sumber data adalah data primer di lapangan atau masyarakat literatur dan merupakan suatu proses untuk menemukan aturan hukum prinsip-prinsip hukum dan juga ketetapan hukum dalam memberikan keadilan untuk wanita bali apabila mengalami perceraian yang terjadi dalam perkawinan biasa di Bali. Teknik analisis data yang digunakan dalam penelitian ini adalah analisis data deskriptif kulitatif. Deskriptif kualitatif yaitu penelitian yang dilakukan untuk menggambarkan suatu variabel secara mandiri, baik satu variabel atau lebih tanpa membuat perbandingan atau menghubungkan variabel dengan variabel lainnya (Narbuko \& Achmadi, 2008).

\section{HASIL DAN PEMBAHASAN}

\section{Kriteria Mulih Daha}

Mulih daha pada dasarnya adalah kembalinya perempuan yang telah kawin keluar kepada keluarga asalnya karena suatu perceraian Bahwa adanya sikap diterima baik-baik oleh pihak keluarga asal dari perempuan yang kembali pulang setelah bercerai secara hukum adat akibat dari suatu perceraian dijelaskan bahwa pihak perempuan dalam perkawinan keluar akan kembali ke rumah asalnya dengan status mulih daha (S. N. Nyoman, 2012). Dalam perkawinan yang dimaksudkan untuk seumur hayatnya namun dalam kenyataannya di dunia ini perkawinan dapat mengalami kegagalan Menurut UndangUndang Nomor 1 Tahun 1974 ada tiga (3) hal yang dapat menyebabkan terjadinya putusnya perkawinan yaitu Kematian salah satu pihak suami atau istri, perceraian dan atas keputusan pengadilan

Dari ketiga alasan putusnya perkawinan akibat perceraian yang menimbulkan adanya mulih daha Sahnya suatu perkawinan didasarkan pada hukum agama dan kepercayaan maka sahnya suatu perceraian harus memenuhi persyaratan hukum agama Di Bali masyarakat yang beragama Hindu perceraian dilakukan di hadapan Pengadilan Negeri yang telah memenuhi persyaratan dan untuk mencegah adanya suatu perceraian ini agama hindu menetapkan hukumnya agar suami dan istri dapat menjalankan tugas dan kewajiban rumah tangganya Namun untuk melegalkan hubungan suami dan 
istri dan juga untuk mendapatkan keturunan serta menjaga hubungan kedua belah pihak (Hilman, 1987).

Istri yang telah melakukan perceraian telah dikembalikan oleh suami atau keluarga suaminya kerumah orang tua pihak istri dan diterima dengan tulus ikhlas oleh pihak keluarga istri Di Bali sulit dijumpai seorang istri mengajukan tuntutan cerai ke Pengadilan namun seorang istri ingin memutuskan perkawinannya dengan atau tanpa alasan yang sah maka dengan begitu saja pulang kerumah orang tuanya untuk meminta perlindungan dari Kepala Desa dan tinggal bersama kedua orang tuanya hingga nantinya suami mengambil tindakan penyelesaian tentang persoalan tersebut

Kriteria mulih daha karena perceraian yang ada di Banjar Munggu tersebut seperi hasil wawancara penulis dengan Bapak I Putu Subrata selaku Klian Adat Banjar Munggu pada tanggal 4 Maret 2020 karena putusnya perkawinan akibat perceraiandengan adanya cerai tersebut maka yang dinamakan status mulih daha (pulang bajang) dengan membawa surat dari pengadilan maka diterima oleh pihak keluarga wanita yang mulih daha tersebut dan dilaporkan kepada Penjuru Adat Setelah disepakati surat perceraian sah tersebut maka Penjuru Adat wajib menyampaikan kepada masyarakat yang ada di Banjar Munggu bahwa dalam rapat banjar yang secara menyeluruh dan dinyatakan wanita tersebut berstatus mulih daha (pulang bajang). Prosedur merupakan suatu rangkaian yang telah ada dan telah dilaksanakan sebelumnya untuk menyelesaikan sesuatu persoalan hingga menemukan suatu pencapaian Prosedur penyelesaian terhadap wanita yang mulih daha adalah suatu penyelesaian yang harus dilakukan oleh wanita tersebut agar mencapai suatu pencapaian yang wajib dilaksanakan bagi wanita tersebut.

Suatu prosedur penyelesaian terhadap wanita yang mulih daha maka penerimaan kembali oleh keluarga wanita merupakan suatu prosedur yang harus ditempuh Namun jika prosedur tidak dilaksanakan maka status pengembalian hak mulih daha tidak diperoleh sehingga membawa konsekuensi yuridis bagi wanita tersebut Untuk memperoleh hak harus ditempuh dengan penerimaan oleh keluarga secara skala dan dilakukan upacara secara niskala yaitu atur piuning atau pemberitahuan kepada para Dewata leluhur bahwa dengan perceraian dengan suaminya anak wanitanya telah kembali kepada orang tuanya dan mohon agar diterima kembali sebagai damuh atau bagian dari keluarga leluhur orang tuanya Dalam atur piuning juga dilakukan upacara secara sahnya perkawinan yang disebut dengan mebiakala serta mapriyascita maksud dari upacara tersebut adalah untuk membersihkan kembali diri wanita dari segala noda yang dibawanya sehingga ia kembali menjadi suci. Dalam upacara ini tidak dilakukan upacara widhi widana namun pemberitahuan kepada masyarakat dalam hal ini kepada Kelian Banjar Kelian Dinas atau kepada pemuka-pemuka adat bahwa seorang wanita telah mulih daha kerumah orangtuanya dan diterima kembali sebagai bagian dari anggota Banjarnya yang tentunya wanita tersebut akan ditapuk atau dipertanggung jawabkan oleh orang tua atau saudarasaudaranya dan jika terjadi sesuatu terhadap wanita mulih daha maka Banjar akan turut bertanggung jawab (Nyoman, 2007). Misalnya wanita mulih daha meninggal dunia Banjar akan ikut sebel atau berbela sungkawa dan diberikan hak untuk mengubur atau melakukan pengabenan pada pekuburan desa adat tersebut Upacara disaksikan oleh Kelian Dadia atau perangkat desa dari pemuka-pemuka adat

Jadi dapat disimpulkan bahwa seorang wanita yang telah mulih daha diwajibkan untuk melangsungkan suatu upacara dan prosedurnya telah diatur dan ditetapkan di banjar munggu tersebut Adapun tujuan dari dilakukanya upacara tersebut untuk memberitahukan kepada leluhur dan orang tuanya bahwa akan ada seorang wanita yang telah menikah keluar kembali lagi ke tempat kediaman awal (orang tuanya) untuk tinggal lagi dan dapat diterima kembali di lingkungan tersebut dengan mendatangkan kelian adat dan kelian banjar agar saksikan bahwa memang seorang wanita tersebut melangsungkan mulih daha agar dapat mempertanggung jawabkan lagi kelak suatu saat wanita tersebut mengalami hal yang bersangkutan dengan banjar

Dalam sistem pewarisan di Indonesia sangat dipengaruhi oleh sistem kekerabatan atau struktur sosial kemasyarakatan setempat Posisi dan peran yang mereka lakukan dalam lingkup keluarga memberikan pengaruh terhadap apa yang kemudian dilakukan dalam masyarakat (Hadikusuma, 2003). dalam hukum adat bali sistem pewarisan yang digunakan tentunya sistem patrilineal yang lebih mengutamakan garis keturunan laki-laki daripada perempuan dikarenakan seorang laki-laki memiliki kewajiban yang lebih besar dibandingkan dengan seorang perempuan sehingga perempuan tersebut hanya mendapatkan bekal dari orang tuanya Dalam Kenyataan sosialnya ada beberapa cara yang dapat ditempuh agar seorang perempuan dapat bagian harta warisan orang tuanya yaitu dengan cara memberikan sebagian harta warisan melalui hibah atau hadiah perkawinan Namun bagaimana dengan 
seorang perempuan yang telah melangsungkan perkawinan kemudian melakukan perceraian sehingga kembali lagi ketempat orang tuanya (mulih daha) apakah perempuan tersebut mendapatkan kembali lagi sebuah status seperti seorang anak yang belum menikah dapat menikmati warisan dari orang tuanya atau bahkan tidak dapat menikmati sedikitpun. Maka dari itu wanita yang mulih daha karena perceraian tidak mendapatkan warisan dari dan harta kekayaan suaminya dan atau harta orang tuanya terkecuali adalah harta yang didapat bersama dalam pewarisan dan untuk di Banjar Munggu tentang ketentuan waris bagi wanita yang mulih daha sangat jelas diatur dalam awig-awig banjar adat Nyatanya perempuan mulih daha yang ada di Banjar Munggu Mengwi ini tidak banyak berperan dalam masyarakat Fungsi mereka dalam masyarakat adalah tidak berperan sama sekali dalam artian kedudukan mereka hanya sebagai anggota keluarga lain dalam keanggotaan orang tua mereka

Masyarakat adat di banjar atau desa adalah yang berstatus berkeluarga Orang tua atau saudara mereka yang telah berkeluarga Dikarenakan jika seorang wanita yang melakukan mulih daha tersebut kembali hanya sementara kemudian menjalin rumah tangga yang baru lagi tentunya wanita tersebut harus melakukan aturan-aturan yang ada di dalam hukum adat yang tertulis disamping dirinya harus melakukan upacara untuk diterima kembali di lingkungan desa dan tempat tinggal orang tuanya perempuan mulih daha harus menyelenggarakan upacara keagamaan pada dua tempat suci apabila wanita mulih daha kelak berkeinginan berumah tangga lagi karena hal ini tentu memberatkan dirinya dalam bidang finansial

\section{Hak dan Kewajiban Wanita yang Mulih Daha}

Pisahnya pasangan suami istri di Banjar Munggu diakibatkan karena Perceraian dalam pasangan suami istri tidak adanya kecocokan lagi sebagai pihak perempuan (istri) pulang kerumah asal dikarenakan sudah tidak adanya tempat tinggal lagi untuk keamanan hidupnya sehingga mengharuskan dirinya untuk kembali lagi bersama orang tuanya atau dalam masyarakat adat di Bali disebut dengan mulih daha Senada dengan penjelasan Merton dalam bahasannya tentang teori fungsionalisme struktural mengenai kultur yakni seperangkat nilai normatif yang terorganisir yang menentukan perilaku bersama suatu anggota masyarakat atau anggota kelompok (Komang, 20178).

Secara adat hak seorang wanita yang mulih daha tidak dapat hak mutlak di rumah asalnya Artinya hak mutlak kaum perempuan pulang kerumah asalnya tidak mendapatkan hak secara purusa kecuali ada itikad baik dari orang tua atau keluarganya Jadi wanita yang mulih daha dengan membawa surat cerai dari pengadilan haknya tidak dapat waris sesuai keikhlasan dari keluarganya kewajibannya yaitu kalau masuk ke banjar munggu dan sudah menjadi warga banjar munggu bagaimanapun apa yang akan dilaksanakan oleh warga lain sama kewajibannya Misalnya kalau seandainya warga lain ada di bawah naungan kakaknya kan yang ayah-ayahan yaitu yang mengajak jadi boleh ikut membantu dimana si warga ini masuk selaku KKnya (Kartu Keluarga) dan otomatis KKnya masuk Jadi hak dan kewajibannya harus ikut berpartisipasi di banjar dimana si perempuan ini kembali dan perlakuan sama hak warga di banjar munggu dengan perlakuan kewajibannya kegiatan apapun yang dilaksanakan di banjar harus ikut kegiatan atau membantu pada kakak-kakak yang mengajaknya apalagi sudah menjadi warga banjar munggu tersebut Apapun kewajibannya yang dilakukan oleh banjar wajib kena sesuai dengan aturan yang berlaku di banjar Jadi lawannya kalau belum resmi menjadi warga banjar munggu walaupun asalnya berbeda atau diajak oleh keluarganya tetapi hanya selaku ayah tumpangan (iuran) maka keluarga yang mengajak harus membayar ayah tumpangan (iuran) tersebut sesuai dengan aturan yang berlaku di banjar munggu.

Dapat disimpulkan bahwa seorang wanita yang melakukan mulih daha masih mendapatkan hak dan kewajibanya di banjar munggu tersebut kewajibanya yakni harus mengikuti ayah-ayahan banjar maupun kegiatan sesuai aturan yang berlaku dan jika belum resmi menjadi masyarakat banjar munggu keluarga maupun orang tuanya wajib membayarkan ayah tumpangan (iuran) sesuai dengan aturan yang berlaku serta mendapatkan haknya seperti masyarakat banjar munggu pada umumnya.

\section{SIMPULAN DAN SARAN \\ 1 Simpulan}

Prosedur dengan penerimaan oleh keluarga secara skala dan dilakukan upacara secara niskala yaitu atur piuning atau pemberitahuan kepada para Dewata leluhur bahwa dengan perceraian dengan suaminya anak wanitanya telah kembali kepada orang tuanya dan mohon agar diterima kembali sebagai damuh atau bagian dari keluarga leluhur orang tuanya Dalam atur piuning juga dilakukan upacara secara sahnya perkawinan yang disebut dengan mebiakala serta maprayascita maksud dari upacara tersebut 
adalah untuk membersihkan kembali diri wanita dari segala noda yang dibawanya sehingga ia kembali menjadi suci dan diberitahukan kepada masyarakat agar resmi kembali menjadi warga desa serta mendapatkan hak dan kewajibanya.

Wanita yang mulih daha tidak dapat ikut serta dalam organisasi desa adat dan seorang wanita yang mulih daha tidak dapat menjadi ahli waris Ia hanya berhak untuk menikmati dan mendapatkan penghidupan dari harta orang tuanya, demikian juga halnya di desa Munggu Mengwi bahwa wanita yang mulih daha tidak sebagai ahli waris seperti dalam Awig-Awig Banjar Munggu pada pawos 89 (5) menyebutkan Wanita balu tidak mendapatkan warisan tetapi boleh memelihara warisannya selama wanita balu itu tinggal di rumah suaminya dan melaksanakan kewajibannya sebagai wanita balu Maka dari itu wanita yang mulih daha karena perceraian tidak mendapatkan warisan dari dan harta kekayaan suaminya dan atau harta orang tuanya terkecuali adalah harta yang didapat bersama dalam pewarisan dan untuk di Banjar Munggu Mengwi tentang ketentuan waris bagi wanita yang mulih daha sangat jelas diatur dalam Awig-Awig banjar Adat

\section{Saran}

Untuk wanita yang akan melakukan perkawinan hendaknya melaksanakan secara sungguhsungguh dengan melakukan ikatan lahir batin antara suami dan istri agar terhindar dari suatu perceraian karena perceraian sangat berdampak terhadap diri wanita anak maupun keluarga wanita tersebut. Untuk seluruh masyarakat di Banjar Munggu Mengwi agar terbuka dan menerima kembali wanita yang melakukan mulih daha baik di dalam kegiatan bermasyarakat dan kegiatan lainya sehingga wanita tersebut bisa memenuhi kembali kewajiban dan haknya sebagai warga desa Banjar Munggu Mengwi.

\section{DAFTAR PUSTAKA}

Fahriyanti, N. (2019). Gugat Cerai: Membebaskan Prempuan dari Penderitaan. Qawwam, 13(2), 101122.

Hadikusuma, H. (2003). Pengantar Ilmu Hukum Adat Indonesia. Mandar Maju.

Hilman, H. (1987). Hukum Kekerabatan Adat. Fajar Agung.

Ketut, K. I. G. (2007). Butir-butir Tercecer Tentang Adat Bali. CV Kayumas Agung.

Ketut, N., \& Adnyani, S. (2019). Akibat Hukum Perceraian terhadap Kedudukan Perempuan dari Perkawinan Asu Pundung. Kertha Wicaksana, 13(2), 121-130.

Komang, A. G. N. (20178). Kedudukan dan Peranan Perempuan Mulih Daha dalam Keluarga dan Masyarakat Bali. Ilmu Sosiologi, 1(1).

Narbuko, C., \& Achmadi, A. (2008). Metodologi Penelitian. Bumi Aksa.

Nasir, B. (2012). Faktor-Faktor yang Mempengaruhi Perceraian di Kecamatan Sungai Kunjang Kota Samarinda. Psikostudia Universitas Mulawarman, 1(1), 31-48.

Nyoman, S. N. (2012). Hak Mewaris Perempuan dalam Hukum Adat Bali Sebuah Studi Kritis. Udayana Universitas Press.

Nyoman, T. I. (2007). Hak Mewaris Wanita yang Mulih Daha dalam Hukum Waris Adat. Airlangga University.

Windia, W. P. (2009). Perkawinan Menurut pada Gelahang di Bali. Udayana Universitas Press. 
Jurnal Interpretasi Hukum

Vol. 1, No. 2, 2020 